\title{
Role of Effective Microorganisms (EM) in Sustainable Agriculture
}

\author{
Himangini Joshi*, Somduttand, Piyush Choudhary and S.L. Mundra \\ Department of Agronomy, Rajasthan College of Agriculture, Maharana Pratap University of \\ Agriculture and Technology, Udaipur, Rajasthan -313 001, India \\ *Corresponding author
}

\section{Ke y words}

Bioremediation, effective

Microorganisms (EM), Living soil

Article Info

Accepted:

04 February 2019

Available Online:

10 March 2019

\section{A B S T R A C T}

Agricultural production is mainly depends on the health of soil, which is a measure of a complex set of biological, chemical and physical interactions driven by microorganisms. Effective microorganism increases the beneficial microbial population in the soil for sustainable crop production. Effective Microorganisms are mixed cultures of beneficial naturally-occurring organisms that can be applied as inoculants to increase the microbial diversity of soil ecosystem. They consist mainly of the photosynthesizing bacteria, lactic acid bacteria, yeasts, actinomycetes and fermenting fungi. EM will improve the structure of the soil, increase its fertility and radically improve biological diversity, suppress soilborne pathogens, fixes the nitrogen in soil and enhances nutrient uptake, accelerates the decomposition of organic waste, residues and composting, increases beneficial minerals in organic compound, enhances the activities of indigenous microorganism and boosts the strength of plants and yield of crops. EM works by being dominant over other soil microbes. As a result, this encourages the bulk of the other microbes in the soil to follow them and in doing so suppress the activity of the smaller group of negative or opportunistic microbes. Effective microorganisms can help to improve and maintain the soil chemical and physical properties.

\section{Introduction}

The human population is increasing day by day and it requires intensifying the existing agricultural production systems. The agricultural production is high due to the immense use of synthetic agrochemicals but environmental deterioration and unsustainable systems are the consequences of these ways of management (Armstrong and Taylor, 2014). The environmentally friendly effective microorganisms (EM) have a large number of benefits when they are applied as manure or spray to the field crops (Alluri et al., 2007).

Cho and Koyama (1997) reported that microorganisms are tiny units of life that are too small; exist everywhere in nature and plays important role in maintaining the ecological balance. Effective Microorganisms are mixed cultures of beneficial naturallyoccurring organisms that can be applied as inoculants to increase the microbial diversity of the soil ecosystem. There is evidence that 
EM inoculation to the soil can improve the quality of soil, plant growth and yield (Han et al., 2006). Healthy soil ecology has the capability of protecting plants against soil born diseases caused by pathogenic microorganisms and parasites. The soil system offers this protection through a balanced relationship between pathogenic and billions of beneficial microorganisms working together in synergy. Chan et al., (2003) observed that presence or absence of these beneficial microorganisms in any soil system precisely distinguishes "living soil" from a "dead soil". They decompose and ferment organic fraction of the soil system converting it into humus containing nutrients while releasing hormones that facilitate plant growth. They are responsible for providing hormones, nutrients and minerals to the plants through the root system. In addition, they bring together soil particles in the soil structure enabling it to retain nutrients and moisture (Kengo and Hui-lian, 2000).

Prof. Dr Teruo Higa worked on the excessive use of chemicals, and then he realized the harmful effects of these chemicals on human beings and environment. Thus, he developed a mixture of beneficial microorganism and he also reported that approximately 80 different types of microorganism are able to decompose organic matter. The concept of EM is based on the inoculation of mixed cultures of beneficial microorganisms into the soil where they shift the microbiological equilibrium and create an environment that is favourable to the growth and health of plants (Goessler and Kuehenelt 2002).

A series of inoculations are made to ensure that the introduced microorganisms continue their dominance over the indigenous populations. The principal organisms are usually five viz. photosynthetic bacteria, lactic acid bacteria, yeasts, actinomycetes and fermenting fungi. These include the suppression of plant pathogens and diseases, conservation of energy in plants, solubilisation of soil minerals, soil microbial-ecological balance, photosynthetic efficiency, and biological nitrogen fixation (Van et al., 1997).

\section{Beneficial effects of effective microorganisms}

Urmi and Sariah (2006) studied that there are numerous benefits to using effective microorganisms in agriculture. Effective microorganisms contribute to soil enrichment, by harmonizing and diversifying native microorganisms. A diversified base of microorganisms will be fed on by earthworms and the number of micro-pores will increase. This makes the soil healthy and results in good growth of plants, pest pressure is reduced and high-quality crops can be grown. This group of bacteria is completely safe for human, plants, animal and soil as it is derived from natural and organic matters (Brown et al., 2000). The usage in agriculture spreads vast and wide in various activities including planting, fertilizing, composting and sanitation as well. The different species of organisms in effective microorganisms complement each other and are in a mutually beneficial relationship with the roots of plants in the soil ecosystem. Plants would, therefore, grow exceptionally well in soils inhabited and dominated by these effective microorganisms (Sun et al., 2014). Effective microorganisms enhance soil fertility and promote growth, flowering, fruit development and ripening in crops. It can increase crop yields and improve crop quality as well as accelerating the breakdown of organic matter from crop residues (Cortez et al., 2000). The population of beneficial microorganisms in the soil is also increased helping to control of soil diseases through competitive exclusion (PostmaBlaauw et al., 2006). Some advantages of using effective microorganisms in agriculture and gardening are explained below. 
Fix the nitrogen in the soil and enhance nutrient uptake

Effective microorganisms will increase nutrient availability in the soil for plants which will reduce the need for constant fertilization and cost of cultivation (Daniel et al., 1992). Foliar application of effective microorganisms results in a large number of beneficial microorganisms at the phyllosphere.

It is believed that certain microorganisms in effective microorganism's culture including photosynthetic bacteria and N-fixing bacteria can enhance the plant's photosynthetic rate and efficiency and $\mathrm{N}$-fixing capacity as well (Pati and Chandra 1981). Vaid et al., (2017) concluded that when bacterial isolates are used in combination they perform better in comparison to their individual use and these isolates significantly increase the mean $\mathrm{Fe}$ concentration in grain and straw by 34 per cent and 52.4 per cent over none inoculated control and also increase the total Fe uptake in comparison to none inoculated controls. The bacterial inoculation also shows a positive impact on the bioavailability of $\mathrm{Fe}$ in the soil. Effective microorganisms enhance nitrogen, phosphorus and potassium nutrition of plant when farmyard manures applied both at flowering and maturity stage. In FYM amended soil effective microorganisms application markedly enhance plant nutrition at later growth stages of mung bean crop (Javaid and Bajwa, 2011). It is said that our vegetables contain much less nutritional value compared with those grown in olden days. EM vegetables have high nutritional value and increased sugar content which improves their taste and allows them to be preserved longer (EMRO, Japan).

\section{Suppressing existing pathogen in soil}

The use of effective microorganisms in agricultural soil not only suppresses soil-borne pathogens but also increases the decomposition of organic materials and consequently the availability of mineral nutrients and important organic compounds to plants (Singh et al., 2003). Introduction of a population of beneficial bacteria in the soil has a supporting effect in reducing soil associated microbiological diseases. The inoculation of effective microorganisms stimulates "Rotation effect", an occurrence that comes as a result of regeneration of beneficial organisms and elimination of pathogenic bacteria. Disease suppression is brought by the completion of available resources between the diseasecausing microbes in the soil and beneficial microbes introduced in effective microorganisms which result in an enhanced population of effective microorganisms through inoculation will deplete the available resources in the soil leading to a reduction of pathogenic microorganisms due to starvation (Johan and Jesper, 2005). Lactic acid has sterilizing effects and its presence in the soil checks the proliferation of nematode population and offers protection against nematode associated plant diseases. Lactic acid bacteria in effective microorganisms also participate in the breakdown of cellulolytic and lignified organic materials in the soil (Ouwehand, 1998).

\section{Accelerate the decomposition of organic waste, residues and composting}

Effective microorganisms consist of common and food-grade aerobic and anaerobic microorganisms. When we pour activated effective microorganisms into environments dominated by putrefactive bacteria, the microbiomes will be improved and foul odors will be suppressed. Altering the microbial environment in the way that effective microorganism will lead to accelerating fermentation of organic matter and a shortening of the period required to manufacture high-quality compost. With the 
application of effective microorganism products, we can efficiently solve problems such as foul odors at waste treatment sites of all kinds like incineration and sewage treatment facility (EMRO, Japan). Hussain et al., (1999) found an increase in wheat and rice grain yield when effective microorganism's application was carried out in combination with farmyard manure and mineral NPK. The higher grain yield in the present and earlier studies, when effective microorganisms were applied in combination with organic matters, can be attributed largely to the activity of the introduced beneficial microorganisms, which enhanced the decomposition of organic materials and the release of nutrients for plant uptake. Jusoh et al., (2013) reported that compost applied with effective microorganism has more $\mathrm{N}, \mathrm{P}$ and $\mathrm{K}$ content compared to compost without effective microorganism. This study suggests that the application of effective microorganism is suitable to increase the mineralization in the composting process. The final resultant compost indicated that it was in the range of the matured level and can be used without any restriction.

\section{Biocomposting by indigenous microorganisms}

The disposal of agro-industrial wastes have become a major problem and due to this most of farmers dispose them through burning. Open burning cause emission of a large amount of harmful air pollutants (particles and inorganic and organic gases), which have severe impact on environment and human health (Korenaga et al., 2001) and the danger of soil erosion and degradation due to repeated burning (Kahlon and Dass, 1987). In addition, disposal in water bodies (for example, river or lake) may contribute to a decrease in water quality and increase the problem of water bloom and eutrophication. Because of these concerns, there is a need to find efficient alternatives for agro-industrial waste management. Composting being one of the most attractive on account of its low environmental impact and cost effective also (Bustamante et al., 2008; Canet et al., 2008 and Lu et al., 2009) as well as its capacity for generating a valuable product used for increasing soil fertility (Weber et al., 2007 and Perez-Murcia et al., 2005). When complex organic materials such as; plants, animal excrements, and organic fertilizers enter into the soil, IMO break down these complex compound into simpler form or elements that can undergo ionic interactions (Anastasia et al., 2004). Compost residues have more benefits than fertilization of crops. A study was conducted by Hanim et al., (2012) to manage Paddy husk and Corn Stalk residues through composting and to determine the physico-chemical properties of different composts and humic acid extracted from the final product. For this study, the results showed that IMO compost from Corn stalk had better quality (chemical characteristics) compared to that of paddy husk. The methods for safe residue management are relatively time consuming but biocomposing is reliable method for most of farmers to recycle residue easily.

\section{Increase beneficial minerals in the organic compound}

Bossuyta and Hendrix (2005) demonstrated that photosynthetic bacteria are independent self-sustaining microorganisms. They harvest energy from the sun and soil heat and use it to convert exudates from root systems, soil organic fraction and gases such as ammonia into building materials of cells such as amino acids, nucleic acids and sugars. These can all be absorbed directly into plants to promote plant growth and also in the soil system promote and maintain the growth and establishment of other beneficial microorganisms. For example, Vesiculararbuscular mycorrhiza fungi known to 
enhance the plant's absorption capability of soil phosphates increases in the root zone in the presence of amino acids secreted by the beneficial bacteria. In addition, in the soil ecosystem, The VAM fungi live in association with Azatobactor and Rhizobium which increase the capacity of plants to fix nitrogen.

\section{Enhance the activities of indigenous microorganism}

Effective microorganism enhances the activities of beneficial indigenous microorganisms, for example, mycorrhizae (ecto as well as endomycorrhizae) which fix atmospheric nitrogen and accelerate phosphorus and zinc uptake from soil thereby supplementing the use of chemical fertiliser and pesticides. Improvement in soil fertility has a significant positive effect on plant growth, flowering, fruit development and ripening in crops (Levai et al., 2006).

Boost the strength of plants and yield of crops

Muthaura et al., (2010) demonstrated that growth and yield of pigweeds improved by inoculating the plants with effective microorganisms, and as a result reduce the use of fertilizers in the production of this vegetable hence promoting sustainable agriculture. EM significantly increased grain yield by 24 per cent and 46 per cent in farmyard manure and NPK fertilizers amendments, respectively in mung bean (Javaid and Bajwa, 2011). Cheng and Yingchun (2013) concluded that long-term application of effective microorganisms' compost could affect soil nematode community structure, wheat biomass and grain yield. Some soil microbes performed as bioinoculants for supplying nutrients and stimulating plant growth and rhizospheric microbes are known for the synthesis of plant growth promoters, siderophores and antibiotics as well as aiding phosphorous uptake. We have seen quick steps made in our appreciation of the diversity of environmental microbes and their possible advantage to sustainable agriculture and for production system. Soil is the major medium where plant exists and takes up nutrients from it and it act as nutrient bin. The "intrinsic bioremediation" and this is one of the best remedial actions for soil contamination (Vaxevanidou et al., 2015).

\section{Benefits of EM in livestock farming}

EM will reduce offensive odors resulting from the build-up of ammonia and trimethylamine which are alkaline. Feeding animals with ration which incorporates effective microorganism Bokashi will improve their internal microbiota and thereby reduce the offensiveness of the odors from manure (Higa, 1991). Spraying effective microorganisms inside the barns as well as adding effective microorganisms to feed and drinking water for animals will improve the microbial environment of the whole barn, including the intestinal bacteria flora of the livestock and maintain the health of the entire operation. As a result, the quality of fat will improve, there is no distinctive meat smell, products will stay fresh for longer periods and the taste and quality of animal products will improve. Also, it is possible to reduce usage of vaccines and antibiotics, thus supporting safer production of animal products from the standpoint of both producers and consumers (EMRO, Japan).

\section{Reduce environmental pollution}

Valls and Lorenzo (2002) revealed that repeated application of effective microorganisms will reduce the need of chemical fertilizers and pesticides in succeeding crops which results in a reduction of environmental pollution. Similarly, they also purify polluted water. Pouring effective 
microorganisms into rivers increases the number of microbes, which form the bottom of the ecological pyramid. When the bottom grows larger, the pyramid itself also becomes larger, resulting in richer diversity in the ecosystem. This will improve the selfpurification ability of rivers, helping them to become clean and beautiful again (Nikolopoulou and Kalogerakis 2010). Mudball is effective microorganisms to activate local and native microorganisms that live in ground and water and maximizes their natural power. These mud balls purportedly contain properties that will purify water, better water quality and solve sanitation problems. In polluted rivers, accumulated sludge is in a state of oxygen deficiency, since there is a little oxygen dissolved in the water. Inside the sludge, harmful fermentation bacteria produce harmful gasses such as methane, ammonia and hydrogen sulphide by decomposing organic matter without oxygen. When mud balls are added to the water with that condition, they become embedded in the surface of the sludge and effective fermentation bacteria contained in mud balls start to decompose the sludge (EMRO, Japan) (Fig. 1-3).

Fig.1 Fixation of atmospheric nitrogen and its beneficial effects on plants and soil

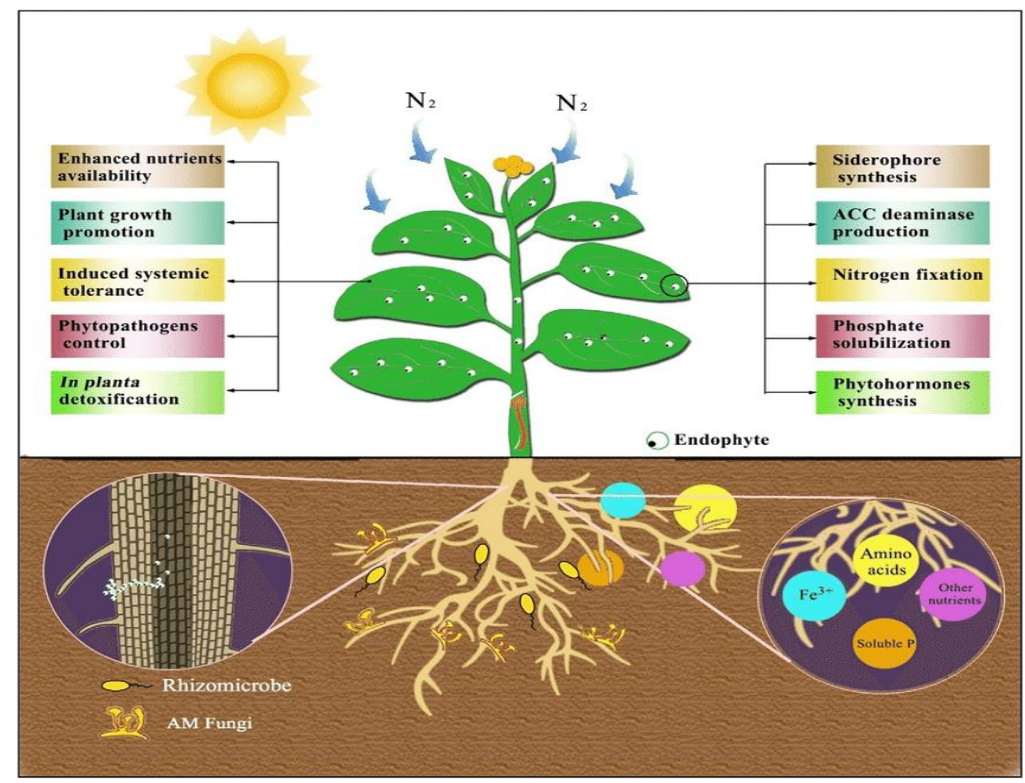

Fig.2 Bioaugmentation of vermicompost biobeds enhanced pesticide degradation
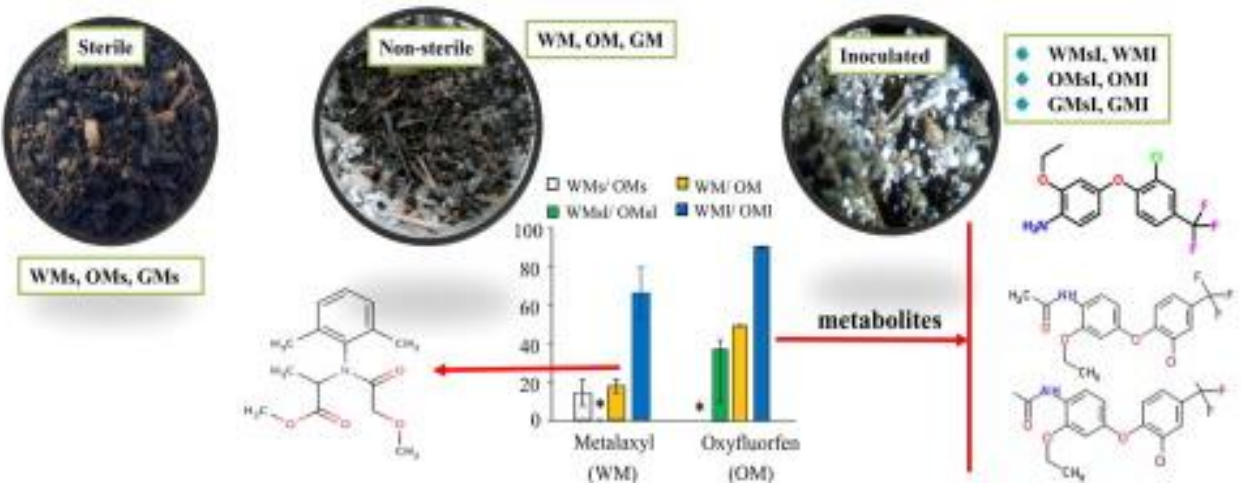
Fig.3 Reuse and recycle of waste residue by effective microorganisms

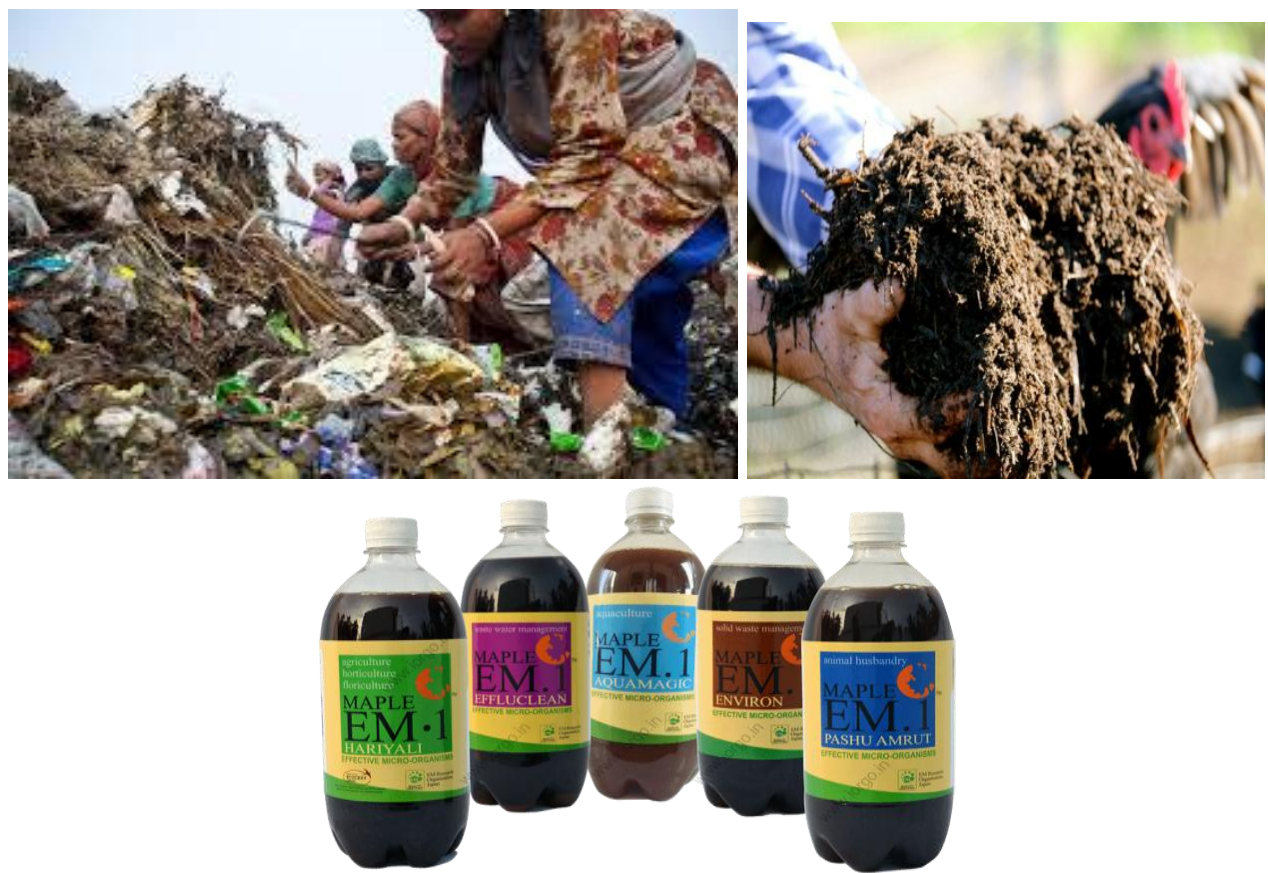

\section{Bioremediation}

The inherent abilities of microorganisms are suitable for the removal of undesirable and heavy metals from solutions (Beveridge and Murray, 1976; Langley and Beveridge, 1999; Nies, 1999). These abilities have been identified as play a passive or active for accumulation and biosorption, respectively, (Brandl and Faramarzi, 2006). Indigenous strains are more suitable to overcome the challenges such as high concentration of these metals, acidic conditions as they had well adapted to conditions in situ. Bacillus strains have been widely used in the removal of such kind of metals $(\mathrm{Pb}, \mathrm{Cd}, \mathrm{Cu}, \mathrm{Ni}, \mathrm{Co}, \mathrm{Mn}, \mathrm{Cr}$, Zn) from wastewaters (Philip and Venkobachar, 2001; Srinath et al., 2003 and Kim et al., 2007) and also from soil solution if applied there to improve inherent quality and fertility of soil.

In conclusion, effective microorganisms are composed of naturally-derived microorganisms, which are safe and eco- friendly. It is not necessary to put on goggles, masks and protective clothing when spraying effective microorganisms. Similarly, effective microorganisms never pollute water systems. The effective microorganism is manufactured from naturally-derived material. It is easy to be decomposed after use and effective microorganism never pollutes groundwater. Instead, it purifies soil, groundwater, lakes and rivers, thereby reducing environmental burdens. The effective microorganism is compatible with various methods of farming, regardless of their scale. It is effective because it diversifies the population of beneficial microorganisms in water. Effective microorganism products help plants grow well which leads to yield increases, longer cultivation periods, and high-quality crops. Together these improvements lead to richer harvests.

\section{References}

Alluri, H.K., Ronda, S.R., Settalluri, V.S., Bondili, J.S., Suryanarayana, V. and 
Venkateshwar, P. 2007. Biosorption: An eco-friendly alternative for heavy metal removal. Afr. J. Biotechnol. 6(25):29242931.

Armstrong, M. and Taylor, M. $13^{\text {th }}$ addition of book Armstrong's Handbook of Human Resource Management Practice 2014.

Anastasia, A., Varese, G.C., Voyron, S., Scannerini, S. and Filipello-Marchisio, V. 2004. Characterization of fungal biodiversity in compost and vermicompost. Compost Science and Utilization 12:185-191.

Beveridge, T.J. and Murray, R.G. 1976. Uptake and retention of metals by cell walls of Bacillus subtilis. J Bacteriol 127:15021518.

Bossuyta, J. Six and Hendrix, P. F. 2005. Comparison of organic compounds in the particle-size fractions of earthworm casts and surrounding soil in humid Laos. Protection of soil carbon by micro aggregates within earthworm casts. Soil Biology \& Biochemistry 37:251-258.

Brandl, H. and Faramarzi, M.A. 2006. Microbemetal-interactions for the biotechnological treatment of metalcontaining solid waste. Chin Particuol 4:93-97.

Brown, G. G., Barois, I. and Lavelle, P. 2000. Regulation of soil organic matter dynamics and microbial activity in the drilosphere and the role of interactions with other edaphic functional domains. European Journal of Soil Biology 36 (4): 177-198.

Bustamante, M., Paredes, C., Marhuenda-Egea, F., Pe'rez-Espinosa, A., Bernal, M. and Moral, R. 2008. Co-composting of distillery wastes with animal manures: carbon and nitrogen transformations in the evaluation of compost stability. Chemosphere 72:551-557.

Cai, M., Yao, J., Yang, H., Wang, R. and Masakorala, K. 2013. Aerobic biodegradation process of petroleum and pathway of main compounds in water flooding well of Dagang oil field. Bioresour Technol 144:100-106.
Canet, R., Pomares, F., Cabot, B., Chaves, C., Ferrer, E., Ribo, M., and Albiach, M.R. 2008. Composting olive mill pomace and other residues from rural southeastern Spain. Waste Manage 28:2585-2592.

Chan, L., Gu, X. and Wong, J. 2003. Comparison of bioleaching of heavy metals from sewage sludge using iron-and sulfur-oxidizing bacteria. Adv Environ Res 7:603-607.

Cho, H.K. and Koyama, A. 1997. Korean natural farming: indigenous microorganisms and vital power of crop/livestock. Korean Natural Farming.

Cheng, H. and Yingchun, Q. 2013. Effective microorganisms and compost favor nematodes in wheat crop. Agronomy for Sustainable Development 33(3): 573-579.

Cortez, J. Billes, G. and Bouche, M. B. 2000. Effect of climate, soil type and earthworm activity on nitrogen transfer from a nitrogen-15-labelled decomposing material under field conditions. Biology and Fertility of Soils 30(4): 318-327.

Daniel, O. and Anderson, J. M. 1992. Microbial biomass and activity in contrasting soil materials after passage through the gut of the earthworm Lumbricus rubellus Hoffmeister. Soil Biology \& Biochemistry 24 (5): 465-470.

EMRO, Japan. Effective Microorganisms Research Organization, 1478-Kishaba, Kitanakagusuku-Sun, Nakagami-Gun, Okinawa 901-2311, Japan. https://emrojapan.com.

Goessler, W. and Kuehenelt, D. 2002. Analytical methods for the determination of arsenic and arsenic compounds in the environment. In: William $\mathrm{T}$, Frankenberger Jr William (eds) CRC Press, pp 27-50.

Higa, T. 1991. Effective microorganisms: A biotechnology for mankind. p.8-14. In J.F. Parr, S.B. Hornick, and C.E. Whitman (ed.) Proceedings of the First International Conference on Kyusei Nature Farming. U.S. Department of Agriculture, Washington, D.C., USA.

Han, H.S., Supanjani, E. and Lee, K.D. 2006. 
Effect of co-inoculation with phosphate and potassium solubilizing bacteria on mineral uptake and growth of pepper and cucumber. Plant Soil Environ 52(3):130 136.

Hanim, A.N., Muhamad, A.N., Ahmed, O.H., Susilawati, K. and Khairulmazmi, A. 2012. Physico-chemical properties of indigenous microorganism-composts and humic acid prepared from selected agroindustrial residues. Afr $J$ Biotechnol 11:8456-8463.

Hussain, T., Javaid, T., Parr, J.F., Jilani, G. and Haq, M.A. 1999. Rice and wheat production in Pakistan with effective microorganisms. American Journal of Alternative Agriculture 14: 30-36.

Javaid, A. and Bajwa, R. 2011. Field evaluation of effective microorganisms (EM) application for growth, nodulation, and nutrition of mung bean. Turkish Journal of Agriculture and Forestry 35: 443-452.

Johan, S. and Jesper, M. 2005. Antifungal lactic acid bacteria as bio preservatives. Trends in Food Science \& Technology 1: 70-78.

Jusoh, M.L., Manaf, L.A. and Latiff, P.A. 2013. Composting of rice straw with effective microorganisms (EM) and its influence on compost quality. Iranian Journal of Environmental Health Science \& Engineering 10(1): 17.

Kahlon, S.S. and Dass, S.K. 1987. Biological conversion of paddy straw into feed. Biol Wastes 22:11-21

Kengo, Y. and Hui-lian, X. 2000. Properties and applications of an organic fertilizer inoculated with effective microorganisms. Journal of Crop Production 3(1): 255268.

Kim, S.U., Cheong, Y.H., Seo, D.C., Hur, J.S., Heo, J.S. and Cho, J.S. 2007. Characterisation of heavy metal tolerance and biosorption capacity of bacterium strain CPB4 (Bacillus spp.). Water SciTechnol J Int Asso Water Pollut Res 55:105-111.

Korenaga, T., Liu, X. and Huang, Z. 2001. The influence of moisture content on polycyclic aromatic hydrocarbons emission during rice straw burning. Chemos Glob Change Sci 3:117-122.

Langley S, Beveridge TJ (1999) Effect of Oside-chain-lipopolysaccharide chemistry on metal binding. Appl Environ Microbiol 65:489-498

Lévai, L., Veres, S.Z., Makleit, P., Marozsán, M., Szabó, B. 2006. New trends in plant nutrition. Proceedings of $41^{\text {st }}$ Croatian and $1^{\text {st }}$ International Symposium on Agriculture, ISBN 953-6331-39-X, pp. 435-436.

Lu, Y., Wu, X. and Guo, J. 2009. Characteristics of municipal solid waste and sewage sludge co-composting. Waste Manage 29:1152-1157.

Muthaura, C., David, M., Musyimi, J.A., Ogur and Samuel, V.O. 2010. Effective microorganisms and their influence on growth and yield of pigweed (Amaranthus dubians). ARPN Journal of Agricultural and Biological Science 4(1): 17-22.

Nies, D.H. 1999. Microbial heavy-metal resistance. Appl Microbiol Biotechnol 51:730-750.

Nikolopoulou, M. and Kalogerakis, N. 2010. Biostimulation strategies for enhanced bioremediation of marine oil spills including chronic pollution. In: Timmis KN (ed) Handbook of hydrocarbon and lipid microbiology. Springer, Berlin, Heidelberg, pp 2521-2529.

Ouwehand, A.C. 1998. Antimicrobial components from lactic acid bacteria. In: Lactic Acid Bacteria: Microbiology and Functional Aspects, Salminen S and Wright AV, (eds.). $2^{\text {nd }}$ Ed., Marcel Dekker Inc., New York, USA. 139 - 159.

Pati, B.R. and Chandra, A.K. 1981. Effect of spraying nitrogen fixing phyllosphere bacterial isolates on wheat plants. Plant and Soil 61:419-427.

Philip, L. and Venkobachar, C. 2001. An insight into the mechanism of biosorption of copper by Bacillus polymyxa. Int $J$ Environ Pollut 15:448-460.

Perez-Murcia, M.D., Moreno-Caselles, J., Moral, R., Perez-Espinosa, A., Paredes, 
C. and Rufete, B. 2005. Use of composted sewage sludge as horticultural growth media: effects on germination and trace element extraction. Comm Soil Sci Plant Anal 36:571-582

Postma-Blaauw, M. B., Bloem, J., Faber, J. H., Van Groenigen, J. W., De Goede, R. G. M. and Brussaard, L. 2006. Earthworm species composition affects the soil bacterial community and net nitrogen mineralization. Pedobiologia 50 (3):243256.

Srinath, T., Garg, S. K. and Ramteke, P. W. 2003. Biosorption and elution of chromium from immobilized Bacillus coagulans biomass. Ind J Exp Biol 41:986-990.

Singh, D.S., Chand, S., Anvar, M. and Patra 2003. Effect of organic and inorganic amendment on growth and nutrient accumulation by Isabgol (Plantago ovata) in sodic soil under greenhouse conditions. Journal of Medicinal and Aromatic Plant Sciences 25: 414-419.

Sun, P.F., Fang, W.T., Shin, L.Y., Wei, J.Y., $\mathrm{Fu}$, S.F. and Chou, J.Y. 2014. Indole-3Acetic Acid-producing yeasts in the phyllosphere of the carnivorous plant Drosera indica L. plos one 9(12): e114196.

https://doi.org/10.1371/journal.pone.0114 196.

Umi, K.M.S. and Sariah, M. 2006. Utilization of microbes for sustainable agriculture in Malaysia: current status. Bio prospecting and management of microorganisms National Conference on Agro biodiversity conservation and sustainable utilization, pp 27-29.

Valls, M. and Lorenzo, V. 2002. Exploiting the genetic and biochemical capacities of bacteria for the remediation of heavy metal pollution. FEMS Microbiol Rev 26:327-338.

Van-Veen, J.A., Van-Overbeek, L.S. and VanElsas, J.D. 1997. Fate and activity of microorganisms introduced into soil. Microbiol Mol Biol Rev 61:121-135.

Vaxevanidou, K., Christou, C., Kremmydas, G.F., Georgakopoulos, D.G. and Papassiopi, N. 2015. Role of indigenous arsenate and iron (III) Respiring microorganisms in controlling the mobilization of arsenic in a Contaminated soil Sample. Bull Environ Cont Toxicol 94(3):282-288.

Vaid, S.K., Kumar, A., Sharma, A., Srivastava, P.C. and Shukla, A.K. 2017. Role of some plant growth promotery bacteria on enhanced $\mathrm{Fe}$ uptake of wheat. Communications in Soil Science and Plant Analysis 48(7): 756-768.

Weber, J., Karczewska, A., Drozd, J., Licznar, M., Licznar, S., Jamroz, E. And Kocowicz, A. 2007. Agricultural and ecological aspects of a sandy soil as affected by the application of municipal solid waste composts. Soil Biol Biochem 39:1294-1302.

\section{How to cite this article:}

Himangini Joshi, Somduttand, Piyush Choudhary and Mundra, S.L. 2019. Role of Effective Microorganisms (EM) in Sustainable Agriculture. Int.J.Curr.Microbiol.App.Sci. 8(03): 172-181. doi: https://doi.org/10.20546/ijcmas.2019.803.024 